\title{
Penerapan Program Gen Aktif (Generasi Anti Kekerasan, Narkoba, dan Zat Adiktif Lainnya) pada Pelajar Kota Ternate
}

\author{
Suparman $^{1, *}$, Bahtiar ${ }^{2}$, M. Nasir Tamalene ${ }^{3}$ \\ ${ }^{1}$ Laboratorium Biologi FKIP Universitas Khairun-Ternate, Maluku Utara, \\ 2,3Program Studi Pendidikan Biologi FKIP Universitas Khairun-Ternate, Maluku Utara, Indonesia \\ *Email: suparman bio@yahoo.com
}

\begin{abstract}
Abstrak
Kota Ternate adalah pusat pelajar di Provinsi Maluku Utara. Beberapa kasus kekerasan dan pengedaran narkoba di Kota Ternate sangat meresahkan pihak orang tua dan sekolah. Studi ini bertujuan untuk mengetahui perubahan pengetahuan siswa sebelum dan setelah mengikuti program GEN AKTIF (Generasi anti Kekerasan, Narkoba, dan Zat Adiktif lainnya). Dua sekolah digunakan sebagai mitra yakni SMP IT Albina Ternate dan SMA Nurul Hasan Kota Ternate. Pelaksanaan program IbM dimulai dengan kegiatan sosialisasi anti narkoba berupa olimpiade anti narkoba untuk pelajar SMA se-kota Ternate. Tahapan kedua ialah pendampingan mengenai GEN AKTIF dan penyuluhan anti narkoba, anti kekerasan dan anti aids. Pendampingan mengambil waktu selama empat bulan yang dilaksanakan disekolah masing-masing. Selanjutnya evaluasi oleh tim pengabdi. Semua rangkaian tersebut dilakukan dengan program IbM pelajar Kota Ternate dalam GEN AKTIF. Rangkaian program melibatkan siswa secara langsung dalam mengelola kegiatan dan pembentukan model komunitas sekolah bernuansa anti kekerasan dan narkoba dikalangan pelajar. Pada akhir program, terdapat peningkatan pengetahuan peserta baik dari SMP maupun SMA tentang narkoba, aids dan kekerasan jika dibandingkan dengan pengetahuan awal peserta, yakni : pengetahuan peserta SMA rata-rata meningkat dari 30\% menjadi $67 \%$; peserta SMP meningkat dari $22 \%$ menjadi $61 \%$ pada tes akhir. Respon peserta juga menyatakan bahwa 100\% peserta senang dengan kegiatan ini, dan $93 \%$ peserta mendapat pengalaman baru dan bermanfaat bagi masa depan
\end{abstract}

Kata kunci: anti narkoba, gen aktif, ibm, ternate.

\section{PENDAHULUAN}

Ternate merupakan pusat Ibukota Maluku Utara sebelum dipindahkan ke sofifi. Tetapi pada kenyataannya, Ternate tetap menjadi pusat perdagangan, pendidikan dan masyarakat Maluku utara. Kota ini merupakan kota di Maluku Utara yang paling ramai diantara yang lainnya dengan kepadatan penduduk 1251,407 jiwa/km (BPS kota ternate, 2014). Ternate dengan luas wilayah hanya 162,03 $\mathrm{km}^{2}$ merupakan pusat kegiatan pendidikan Maluku Utara yang memiliki SD sebanyak 112 sekolah dan 21.462 peserta didik; 26 SLTP dengan jumlah murid 6.960 orang; jenjang SMU sebanyak 17 sekolah dengan 6.021 siswa. Pada jenjang tinggan tinggi, Ternate terdapat 6 Perguruan Tinggi negeri dan swasta, yaitu : Universitas Khairun, IAIN, UMMU Muhammadiyah Maluku Utara, AIKOM Ternate, STIKIP dan Politeknik Depkes Ternate.

Banyaknya fasilitas semua jenjang pendidikan di Ternate menjadikan Ternate sebagai pusat pendidikan bagi Maluku Utara. Hal ini tentu membawa imbas bagi perekonomian dan perdagangan juga bagi kehidupan sosial dan remaja. Banyaknya jumlah remaja cenderung lebih mudah menyebarkan arus dan modernisasi yang tidak terkontrol. Hal ini menjadikan Ternate daerah rawan dengan kehidupan remaja, kekerasan dan perkelahian pelajar. Beberapa catatan kejadian bentrok dan perkelahian remaja, pelajar serta peredaran narkoba yang dapat diajdikan referensi diantaranya ialah: perkelahian mahasiswa pada 19 Januari 2012 di Fakultas Keguruan dan IImu Pendidikan (FKIP) Universitas Khairun, Ternate, Maluku Utara saling serang dan lempar batu dikarenakan adanya hal yang prokontra dua kelompok terhadap etika dosen (Okezone, 2012); Perkelahian antar pelajar juga terjadi antara kelompok siswa SMK 2 Ternate dan SMA 4 Kota Ternate pada 15-16 November 2015.

Kejadian demonstrasi mahasiswa yang berakhir anarkis selalu berulang di Wilayah Ternate baik oleh mahasiswa maupun pelajar. Hal ini tentu membawa citra buruk bagi dunia pendidikan dan menjadikan suatu kebiasan yang sangat tidak baik bagi kehidupan perkembangan pelajar di Ternate. Ternate sebagai kota kecil bahkan telah juga dimasuki oleh penyebaran narkoba dan zat adiktif lain 
yang ikut memicu kekerasan dan kriminalitas dalam dunia remaja.

Secara nasional menyalahgunaan narkoba memang menjadi masalah serius. Berdasarkan data yang dikeluarkan oleh Badan Narkotika Nasional, penggunaan NAPZA yang diluar kendali atau penyelahgunaan pada kasus Narkotika meningkat $28,9 \%$ pertahun. Begitu juga dengan kasus-kasus kejahatan yang berhubungan dengan zat adiktif dan psikotropika mengalami peningkatan $28,6 \%$ tiap tahun (Wulandari dkk, 2015). Berbagai upaya pencegahan penyalahgunaan narkoba terus dilakukan pemerintah bekerjasama dengan masyarakat. Hal ini karena narkoba beredar tidak hanya pada kalangan remaja dan kriminal tetapi juga pada berbagai kalangan. Dalam penelitian Solihah (2015), memaparkan program pencegahan narkoba pada kalangan tenaga kerja berupa P4GN (program pencegahan, pemberantasan penyalahgunaan dan peredaran gelap narkoba) dilakukan juga pada para pekerja. Hal ini bertujuan agar para karyawan dan seluruh tenaga kerja memiliki pemikiran, afektif dan juga terampil menolak penyalahgunaan dan peredaran gelap narkoba.

Peredaran narkoba telah menyerang banyak wilayah di Indonesia. Peredaran narkoba di Ternate tak terbendung, bahkan hal ini menjadikan ternate potensi untuk sarang narkoba (Deliknews.com, 2016). Berdirinya gedung BNN di kota ternate tidak langsung mengurangi peredaran narkoba di wilayah tersebut. Bahkan kasus peredaran narkoba telah sampai sel tahanan. Hal ini juga tidak memungkinkan bahwa peredaran narkoba telah sampai pada kalangan remaja dan pelajar. Untuk mengantisipasi dan melakukan pencegahan peredaran narkoba, maka beberapa sekolah secara aktif berusaha mencegah dengan berbagai cara. Diantaranya dengan berdiskusi dengan pihak kampus untuk mencari solusi bersama terhadap perederan narkoba.

Pada beberapa kasus penyelahgunaan narkoba, sering didaptkan hal tersebut karena banyak faktor baik dari lingkungan sekolah, baik teman akak tingkat atau juga dari pihak keluarga. Pada penelitian lain didapatkan bahwa penyalahgunaan narkoba terkait dengan tingkat keyakinana terhadap agama yang rendah. Pada penelitian Rahmadona dan Agustin (2014), menunjukan bahwa lebih dari setengah pengguuna narkoba dalam penelitiannya merupakan pemeluk agama yang kurang religius. Lebih lanjut peneliti mengungkapkan bahwa $41,7 \%$ pengguna narkoba adalah berasal dari keluarga yang kurang tanggap terhadap pencegahan penyalahgunaan narkoba. Bahkan hampir semuanya $(71 \%)$ terpengaruh oleh teman yang mempengaruhi dan mengajak penyalahgunaan narkoba. Penyalahguna Narkoba, pada penelitian lain dijelaskan bahwa memeiliki kecendrungan hubungan yang kurang baik dengan keluarga, bahkan merasa ditolak dan tidak diakui dalam ingkungan keluarga (Purnomowardhani dan Koentjoro, 2000). Penggunaan narkoba dan minuman keras serta zat adiktif meluas di kalangan siswa, dengan sasaran utama di Sekolah Menengah Atas dan Perguruan Tinggi (Hidayati dan Indarwati, 2012). Beberapa hal yang mendorong penggunaan narkoba pada remaja ialah karena ingin terlihat gaya, solideritas kelompok atau teman, menghilangkan rasa sakit dan coba-coba (Amanda dkk, 2017).

Hasil diskusi pihak sekolah dengan pengusul program Iptek bagi Masyarakat (IbM) secara bertahap termasuk dengan siswa yang aktif dalam organisasi menghasilkan kesepakatan bersama bahwa diperlukan cara-cara sosialisasi dan pencegahan yang konstruktif dan menarik bagi pelajar. Sosialisasi dan pencegahan kekerasan diharapkan tidak monoton dan membosankan sehingga dapat menarik banyak pihak untuk ikut serta. Kegiatan pencegahan peredaran narkoba yang akan dilakukan dapat mengadopsi dari kegiatan serupa diberbagai tempat. Salah satunya ialah kegiatan yang dilakukan BNN Propinsi Yogyakarta dengan melibatkan pihak sekolah meliputi kepala sekolah, guru-guru, termasuk pelajar dan lingkungan sekolah. Hasli dari kegiatannya ternyata dapat meningkatkan pembentukan kader anti narkoba dan memicu sekolah dalam membuat progran mencegahan peredaran narkoba (Wulandari, 2016).

Peneliti dalam hal ini mewawancarai pihak SMA IT Nurul Hasan yang menginginkan kegiatan ekstrakurikuler dapat membantu dalam sosialisasi dan pencegahan anti kekerasan dan narkoba, hal yang sama juga pada sekolah SMP IT Albina Ternate. Maka Kepala sekolah SMA IT Nurul Hasan dan kepala sekolah SMP IT Albina Ternate sepakat dengan pengusul IbM dan bersedia menerima model sosialisasi anti kekerasan dan pencegahan peredaran narkoba. Berdasarkan hasil diskusi 
tersebut, maka secara bersama melakukan identifikasi persoalan mitra. Masalah utama pada mitra yang teridentifikasi ialah: 1 . Terdapat masalah pada pelajar Kota Ternate yakni penyebaran narkoba dan obat-obatan terlarang lainnya pada remaja dan sekolah-sekolah; 2. Pihak mitra membutuhkan pola sosialisasi efektif untuk mencegah penyebaran penyalahgunaan narkoba khususnya pada pelajar di dalam lingkungan sekolahnya; 3. Karakter siswa di sekolah mitra seperti pada umumnya pelajar di Ternate cenderung keras dan sulit..

Berdasarkan latar belakang dan permasalah mitra tersebut, maka penulis tertarik untuk melakukan studi terhadap keberhasilan program Iptek Bagi Masyarakat dengan nama Gen aktif (Generasi anti kekerasan, narkoba dan zat adiktif lainnya) pada pelajar Kota Ternate. Maka tujuan penelitian ialah untuk melihat peningkatan pengetahuan siswa setelah mengikuti program Gen Aktif serta bagaimana respon siswa terahdap pelaksanaan program.

\section{METODE}

Metode dalam penelitian ini adalah berupa metode eksperimen dengan analisis deksriptif kualitatif. Eksperimen dengan pemberian perlakuan berupa program gen aktif pada peserta yang terdiri dari 15 siswa SMP dan 15 siswa SMA. Program Gen aktif terdiri dari pendampingan, pelatihan dan pembentukan kader gen aktif. Sebelum dan pasca program semua peserta diberikan tes kognitif yang terdiri dari pengetahuan tentang anti narkoba, kekerasan, anti AIDS dan undang-undang tentang narkoba.

Tes tersebut berguna untuk melihat perkembangan kemajuan siswa sebagai bahan evaluasi tim pengabdian masyarakat. Diakhir program, para peserta juga diminta mengisi angket dan wawancara mengenai program gen aktif yang dilakukan.

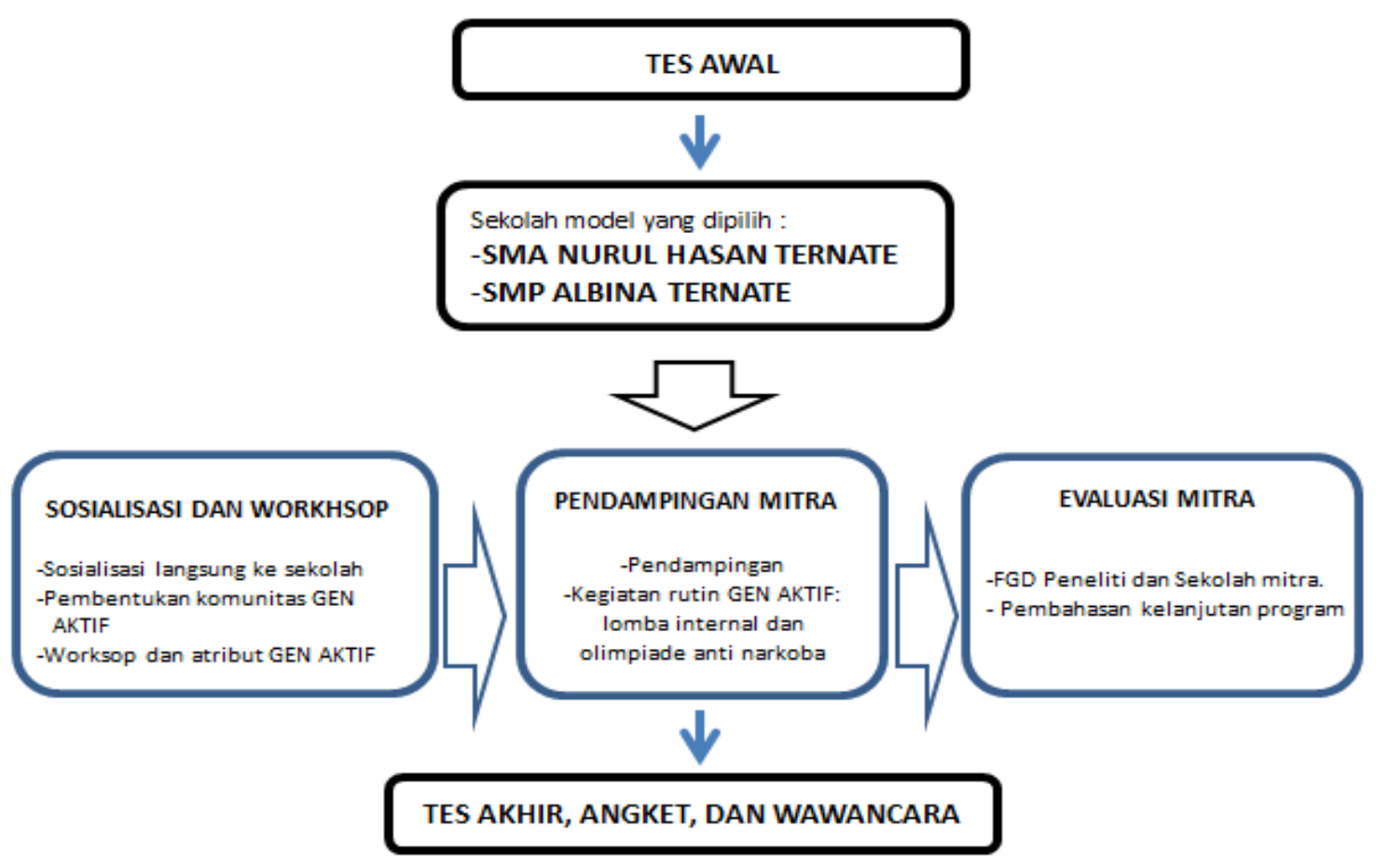

Gambar 1. Metode penelitian terdiri dari pretest, penerapan program gen aktif pada pelajar Kota Ternate dan diakhiri dengan posttest, pengisian angket dan wawancara. 


\section{Pelaksanaan Program}

\section{HASIL DAN PEMBAHASAN}

Program telah dilakukan dalam tiga kegiatan utama yakni : 1. Olimpiade anti narkoba, 2. Penyuluhan, 3. Pendampingan GEN AKTIF. Ketiga kegiatan tersebut dilakukan secara terintegratif dan secara tumpang tindih antara ketiga kegiatan tersebut serta tidak kaku. Pada olimpiade, materi yang dilombakan meliputi materi-materi anti narkoba dan anti kekerasan. Olimpiade anti narkoba sebagai bentuk sosialisasi se-Kota ternate diikuti oleh 59 peserta dari 12 sekolah yang ada di Ternate. Olimpiade khusus dilakukan untuk tingkat SMA. Adapun kisi-kisi materi olimpiade adalah sebagai berikut:

Tabel 1. Materi dan indikator olimpiade anti narkoba

\begin{tabular}{|c|c|c|c|}
\hline No & Materi & Indikator & $\begin{array}{l}\text { Persentase } \\
\text { (jumlah) soal }\end{array}$ \\
\hline \multirow[t]{3}{*}{1} & \multirow{3}{*}{$\begin{array}{l}\text { Peraturan dan perundangan } \\
\text { narkoba meliputi }\end{array}$} & Undang-undang tentang narkoba, & $12(7)$ \\
\hline & & peraturan pemerintah & $12(7)$ \\
\hline & & $\begin{array}{l}\text { Peraturan menteri dan hukum- } \\
\text { hukum penggunaan narkoba }\end{array}$ & $10(6)$ \\
\hline \multirow[t]{4}{*}{2} & \multirow[t]{4}{*}{ Jenis dan bahaya narkoba } & Jenis-jenis dan golongan narkoba & $8(5)$ \\
\hline & & $\begin{array}{l}\text { bahaya dan dampaknya bagi } \\
\text { manusia }\end{array}$ & $8(5)$ \\
\hline & & $\begin{array}{l}\text { cara penanggulangan terhadap } \\
\text { narkoba; }\end{array}$ & $8(5)$ \\
\hline & & berbagai istilah dalam narkoba & $8(5)$ \\
\hline 3 & $\begin{array}{l}\text { Lembaga-lembaga khusus } \\
\text { yang menangani kasus } \\
\text { narkoba }\end{array}$ & $\begin{array}{l}\text { BNN Pusat; BNN Wilayah; } \\
\text { Kemenkes }\end{array}$ & $17(10)$ \\
\hline 4 & $\begin{array}{l}\text { Anti Kekerasan dan } \\
\text { pengetahuan tentang AIDS }\end{array}$ & $\begin{array}{l}\text { Anti Kekerasan dan pengetahuan } \\
\text { tentang AIDS }\end{array}$ & $17(10)$ \\
\hline
\end{tabular}

Tabel 2. Daftar pemenang Olimpiade Anti Narkoba Se-Kota Ternate 2017:

\begin{tabular}{llll}
\hline PEMENANG & NAMA PESERTA & SKOR & ASAL SEKOLAH \\
\hline Juara I & Nurul Safitri & 86,67 & SMAN 2 Ternate \\
\hline Juara II & Raja omar razoki harahap & 85,00 & SMAN 1 Ternate \\
\hline Juara III & Ilfahri Usman Lawarang & 83,34 & SMAN 10 Ternate \\
\hline Juara IV & Siti Hadjar A Rahman & 81,67 & SMA IT Nurul Hasan Ternate \\
\hline Juara V & Ramadhan Abd Rahim & 80,00 & SMAN 2 Ternate \\
\hline Juara VI & Yusril Rafiqzal Zuldan & 78,33 & SMAN 1 Ternate \\
\hline
\end{tabular}

Saat penyuluhan hanya dilakukan pada dua sekolah mitra yakni SMA IT Nurul Hasan dan SMP IT Albina yang keduanya berada di Kota Ternate. Adapun materi penyuluhan adalah sesuai dengan target capaian materi peserta yakni meliputi materi undang-undang narkoba, bahaya narkoba, pengetahuan anti kekerasan dan pengetahuan tentang AIDS dan penyakit menular seksual lainnya. Tabel 3. Jadwal kegiatan penyuluhan dan pembukaan pendampingan GEN AKTIF

Hari I.

\begin{aligned} & \hline JAM \\ & \hline $08.00-09.00$ Persiapan/pembukaan \\ & \hline $09.00-10.50$ Materi I : Pengenalan program dan kontrak kegiatan dengan peserta \\ & \hline $11.00-12.45$ Materi II (peraturan, undang-undang, dan hukum-hukum ttg narkoba) \\ & \hline $12.45-13.45$ ISHOMA \\ & \hline $13.30-15.15$ Materi III (Bahaya dan penanganan narkoba) \\ & \hline $15.15-16.00$ Simulasi \\ & \hline\end{aligned}


Hari II.

\begin{tabular}{ll}
\hline JAM & \\
\hline $08.00-09.00$ & Senam pagi, permainan \\
\hline $09.00-10.50$ & Materi IV (Bahaya dan penanganan narkoba lanjutan) \\
\hline $11.00-12.45$ & $\begin{array}{l}\text { Materi V (peraturan, undang-undang, dan hukum-hukum ttg narkoba } \\
\text { lanjutan) }\end{array}$ \\
\hline $12.45-13.45$ & ISHOMA \\
\hline $13.30-15.30$ & Materi VI (Anti Kekerasan, anti narkoba, dan anti AIDS) \\
\hline $15.30-16.00$ & Simulasi dan penutupan \\
\hline
\end{tabular}

Pendampingan gen aktif dilakukan selama dua bulan dengan pola bimbingan, yakni tim pengabdian memberikan dan sosialisasi secara rutin yang disisipkan dalam kegiatan ekstrakurikuler. Dalam proses pendampingan terdiri dari 30 peserta yang merupakan calon kader gen aktif di sekolah tersebut, yakni 15 orang dari tingkat SMA dan 15 orang dari tingkat SMP.Semua kader tersebut dilatih menjadi kader GEN AKTIF yakni Generasi Anti Kekerasan dan zat adiktif. Gen aktif inimerupakan komunitas yang melakukan kampanye dalam sekolah yang utamanya terhadap diri sendiri untuk menjauhi Narkoba, zat-zat terlarang lainnya, menjauhi kekerasan dan menjauhi AIDS dan sejenisnya. Kader-kader komunitas gen aktif diberikan tanda yakni Topi, PIN, dan Bet anti narkoba. Atribut tersebut diberikan setelah melalui kegiatan penyuluhan dan pendampingan anti narkoba. Pendampingan dilakukan secara nonformal berupa kegiatan-kegiatan kelas dan lapangan yang berbentuk simulasi. Kegiatan dilakukan pada hari sabtu sehingga tidak menggangu jam sekolah.

Setelah rangkaian kegiatan pendampingan dilakukan evaluasi berdasarkan perkembangan peserta dari hasil tes dan respon terhadap pelaksanaaan program. Bahan evaluasi terdiri dari hasil pretes dan postes; hasil angket peserta kegiatan; dan hasil wawancara serta evaluasi dari pihaj mitra.

\section{Tes pretes dan post test}

Tes yang dilakukan pada awal dan akhir meliputi pengetahuan siswa tentang kenarkobaan dan berbagai zat adiktif lainnya, kekerasan, dan pengetahuan seputar AIDS. Pada sekolah mitra SMA Nurul Hasan, tes awal menunjukan nilai terendah yakni 20 dan nilai tertinggi adalah 45 dengan ratarata 30. Pada SMP Albina menunjukan nilai tes awal yang rebih rendah, yakni nilai rata-rata ialah 22 dengan nilai terendah 10 dan nilai tertinggi 30. Perbedaan nilai rata-rata pada tes awal ini menunjukan kemampuan jenjang masing-masing. Hal ini dikarenakan soal tes yang digunakan sama, sehingga terlihat bahwa kemampuan kognitif siswa SMA terhadap pengetahuan tentang narkoba, kekerasan, dan AIDS secara rata-rata lebih tinggi dibandingkan dengan siswa SMP.

Pada hasil tes akhir juga terdapat perbedaan nilai rata-rata dari masing-masing jenjang. Ratarata tes akhir pada peserta yang berasal dari siswa SMA ialah 67 sedangkan rata-rata pada jenjang SMP ialah 61. Hal ini menunjukan bahwa kemampuan kognitif peserta berdasarkan nilai rata-rata setelah mengikuti program lebih tinggi pada jenjang SMA dibandingkan jenjang SMP. Tetapi rentang peningkatan pengetahuan pada jenjang SMP tinggi dibandingkan jenjang SMA. Pada jenjang SMP rentang peningkatannya ialah $39 \%$, yakni dari rata-rata tes awal 22 menjadi 61 . Sedangkan pada jenjang SMA peningkatannya ialah 37\%, yakni dari 30 menjadi 67. 


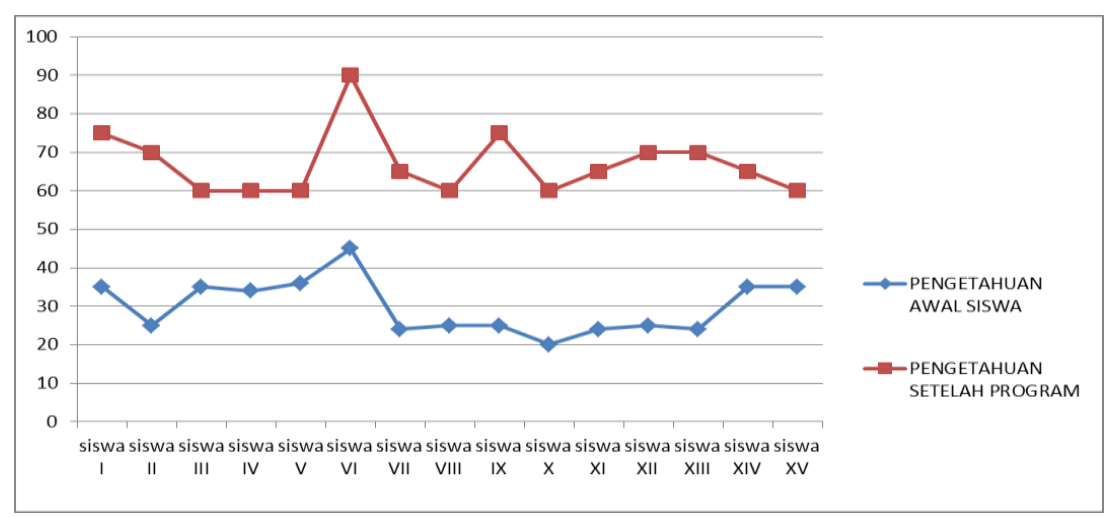

Gambar 2. Grafik perubahan pengetahuan siswa SMA IT Nurul Hasan tentang Narkoba, Anti kekerasan dan AIDS Sebelum dan sesudah mengikuti program Gen aktif

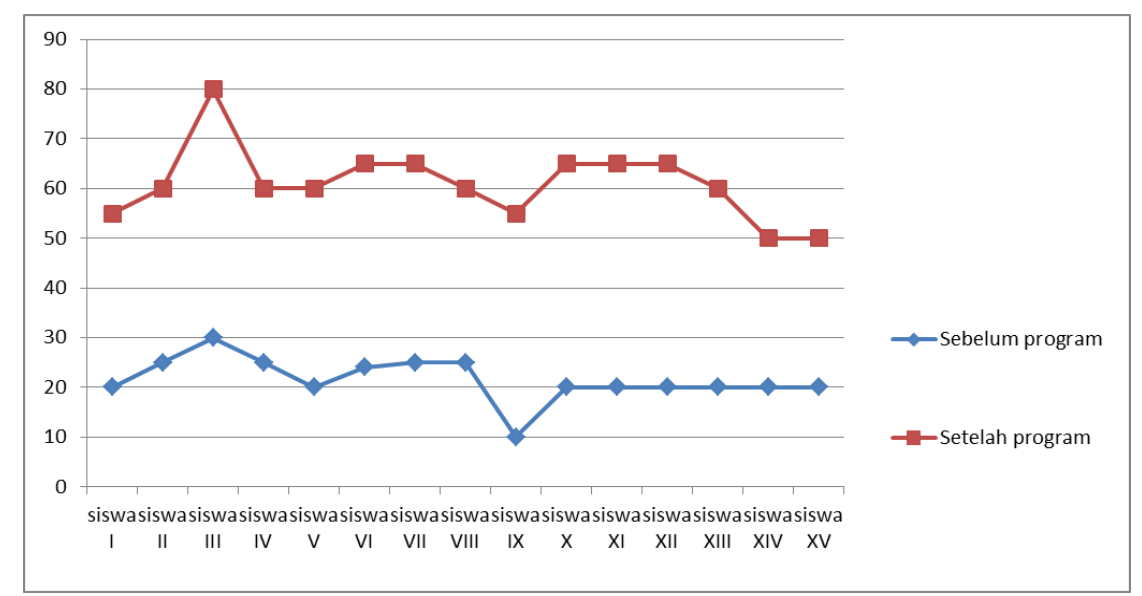

Gambar 3. Grafik perubahan pengetahuan siswa SMP IT Albina tentang Narkoba, Anti kekerasan dan AIDS Sebelum dan sesudah mengikuti program Gen aktif

\section{Hasil evaluasi angket dan wawancara}

Hasil evaluasi diambil dari semua instrumen meliputi borang capaian pengabdian, tes tertulis terhadap pengetahuan siswa, angket, wancara, dan respon peserta dari sekolah mitra dan peserta olimpiade anti narkoba. Berdasarkan hasil evaluasi tim pelaksana pengabdian maka beberapa hal yang menjadi kendala dalam pelaksanaan program perkegiatan ialah pengaturan jadwal pendampingan dengan peserta program. Kegiatan pendampingan tidak boleh mengganggu jam sekolah siswa, sedangkan kedua sekolah yakni SMA IT Nurul Hasan dan SMP IT Albina merupakan sekolah yang menerapkan full day school, yakni siswa berada di sekolah dari jam 7.15 sampai jam 16.30. Sehingga pengaturan jadwal pendampingan hanya dapat dilakukan pada hari sabtu saat kegiatan ekstrakurikuler tetapi hanya setengah hari. Sehingga jam pendampingan sangat terbatas. Pada SMA IT Nurul Hasan memiliki kebijakan bahwa hari minggu tidak boleh digunakan untuk kegiatan sekolah, hal ini agar siswa dapat beristirahat. Setalah enam hari beraktivitas di sekolah.

Semua siswa yang tidak mengikuti ekstrakurikuler wajib pramuka yang pelaksaannya dilakukan pada hari sabtu. Hal ini membuat program pendampingan menjadi sangat sempit. Dari 16 jam pendampingan yang direncanakan hanya terlaksana 10 jam. Beberapa jam diantaranya digabungkan dalam beberapa hari. Pendampingan dilakukan bersamaan dengan pelaksanaan ekstrakurikuler 


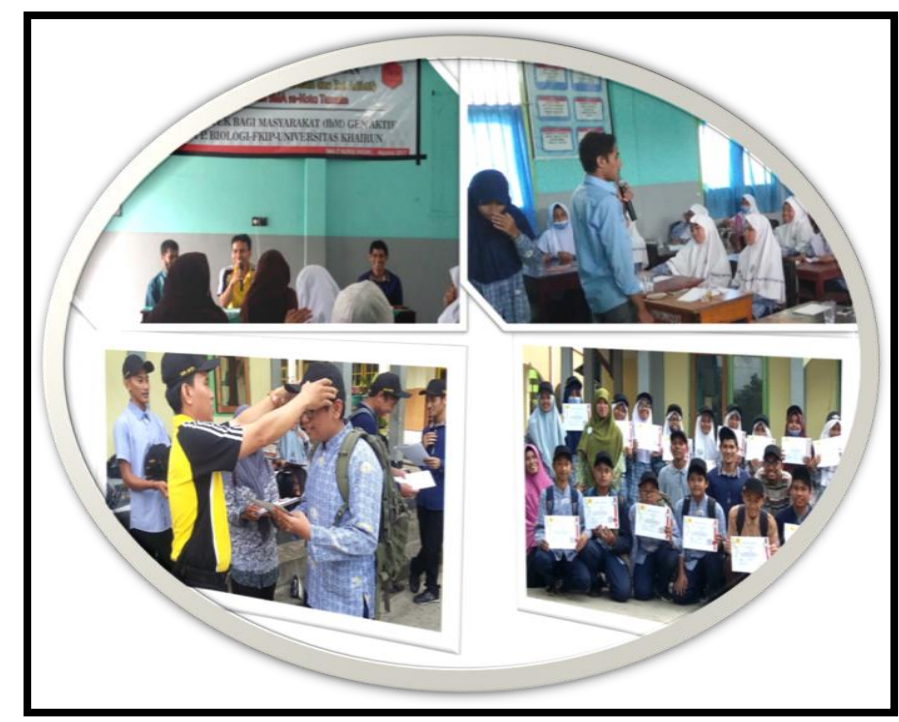

Gambar 4. Rangkaian kegiatan pendampingan dan penyuluhan gen aktif

Mitra yang terlibat secara keseluruhan ialah dua sekolah utama dengan komposisi sebagai berikut : pendidikan mitra S2 sebanyak 1 orang; S1 sebanyak 4 orang. Kesemuanya adalah guru dan kepala sekolah. Sedangkan mitra yang berpendidikan SMA atau sementara sedang pendidikan SMA 15 orang, dan pendidikan SMP 15 orang. Pelibatan sekolah lain juga ada pada saat pelaksanaan olimpiade anti narkoba yakni terdata sebanyak 12 SMA dan sederajat se-Kota Ternate dengan jumlah peserta 59 peserta. Salah satu tujuan tersirat dari program ini, selain memberikan pengetahuan anti narkoba, diharapkan juga dapat memicu keterampilan dan kemampuan berpikir kreatif siswa. Kemampuan berpikir kreatif merupakan suatu yang penting bagi kehidupan siswa. Hal ini dilakukan dengan pola pendampingan berupa simulasi dan pemberian berbagai masalah yang mengadopsi dari Problem Based Learning (PBL). Hal ini sesuai dengan hasil penelitian Suparman dan Husen (2015) bahwa kemampuan berpikir kreatif dapat ditingkatkan dengan pola PBL.

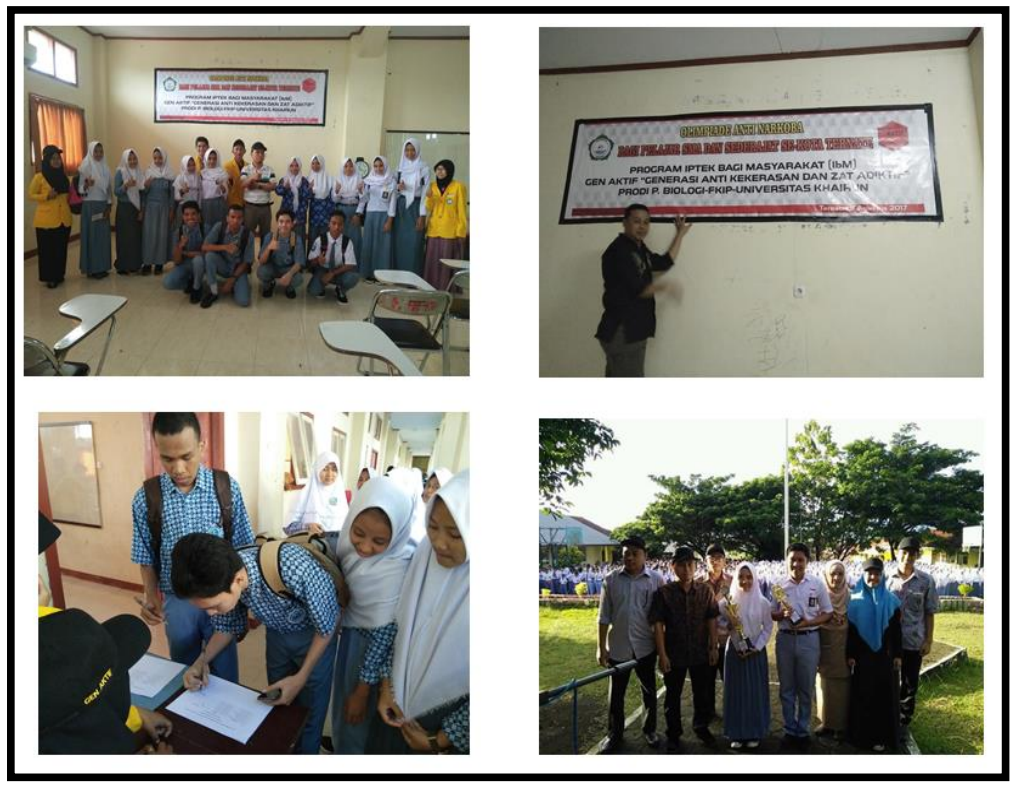

Gambar 5. Rangkaian kegiatan olimpiade anti narkoba se-Kota Ternate

Respon terhadap pelaksanaan pendampingan GEN AKTIF dari peserta mitra sangat positif. Hal ini berdasarkan data angket yang disebar dari 30 peserta, yakni 28 orang (93\%) menunjukan bahwa mereka mendapat pengalaman baru; $100 \%$ peserta senang dengan program yang dilakukan; $97 \%$ peserta mendapat banyak pengetahuan tentang bahaya narkoba; $83 \%$ mengatakan mendapat 
pengalaman berharga. Kegiatan ini merupakan bagian usaha untuk mengurangi kasus narkoba, sebagaimana terdata oleh BNN sepanjang 2007-2012 saja banyak kasus narkoba pada rentang usia sekolah yakni dari 189.294 tersangka kasus, 47,50\% diantaranya ialah usia 16-29 tahun (Handoyo \& Atmosukarto, 2016).

\section{PENUTUP}

Penerapan program Gen aktif pada pelajar Kota Ternate yang diwakili oleh dua sekolah mitra yakni SMP IT Albina dan SMA IT Nurul Hasan telah dilakukan dalam tiga kegiatan utama yakni penyuluhan, pendampingan kader gen aktif, dan olimpiade anti narkoba. Rata-rata pengetahuan peserta meningkat dari tigapuluh persen menjadi enampuluh tujuh persen pada tingkat SMA dan $20 \%$ menjadi $61 \%$ pada siswa SMP. Respon peserta yang berjumlah tiga puluh orang sebagai berikut: 93\% diantaranya mendapat pengalaman baru; $83 \%$ mendapat pengalaman berharga; semua peserta atau $100 \%$ senang dengan kegiatan gen aktif.

\section{DAFTA PUSTAKA}

Amanda, M. P., Humaedi, S., \& Santoso, M. B. (2017). Penyalahgunaan Narkoba Di Kalangan Remaja (Adolescent Substance Abuse). Prosiding Penelitian dan Pengabdian kepada Masyarakat, 4(2): 129-389.

BPS Kota Ternate. (2014). Maluku Utara dalam Angka 2011. Badan Pusat Statistik Maluku Utara.

Deliknews. (2016). Kapolda Malut Sebut Ternate Sarang Narkoba. Diakses 12 Desember 2017. Diakses dari: https://www.deliknews.com/2016/05/04/kapolda-malut-sebut-ternate-sarang-narkoba/

Handoyo, P., \& Atmosukarto, I. (2016). 40 Tahun "Perang Melawan Narkotika": Pengelolaan Narkotika oleh Negara, Perang Bukan Solusi. Jurnal Peradilan Indonesia. 5: 9-26.

Hidayati, P. E., Indarwati. (2012). Gambaran Pengetahuan dan Upaya Pencegahan Terhadap Penyalahgunaan Narkoba Pada Remaja di SMK Negeri 2 Sragen Kabupaten Sragen. Gaster/ Jurnal Ilmu Kesehatan, 9(1), 15-21.

Okezone (2012). Bentrok Pelajar Sepanjang 2012. Diakses dari: https://news.okezone.com/read/2012/10/19/417/706275/bentrok-mahasiswa-sepanjang-2012

Purnomowardani, A.D., \& Koentjoro. (2000). Penyingkapan-Diri, Perilaku Seksual, dan Penyalahgunaan Narkoba. Jurnal Psikologi, 27(1), 60-72.

Rahmadona, E., \& Agustin, H. (2014). Faktor yang berhubungan dengan penyalahgunaan narkoba di rsj prof. hb. sa'anin. Jurnal Kesehatan Masyarakat Andalas, 8(2), 60-66.

Sholihah, Q. (2015). Efektivitas Program P4GN Terhadap Pencegahan Penyalahgunaan NAPZA. Jurnal Kesehatan Masyarakat, 10(2), 153-159.

Suparman, \& Husen, D.N. (2015). Peningkatan Kemampuan Berpikir Kreatif Siswa Melalui Penerapan Model Problem Based Learning. Bioedukasi, 3(2): 367-372.

Wulandari, C. M., Retnowati, D. A., Handojo, K.J., \& Rosida. (2015). Faktor-Faktor Yang Mempengaruhi Penyalahgunaan Napza Pada Masyarakat Di Kabupaten Jember. Jurnal Farmasi Komunitas, 2(1): 1-4.

Wulandari, T. (2016). Implementasi Kebijakan Pencegahan Dan Pemberantasan Penyalahgunaan dan Peredaran Gelap Narkoba (P4GN) Pada Kalangan Pelajar Di BNNP DIY. Jurnal Kebijakan Pendidikan, Spektrum Analisis Kebijakan Pendidikan, 5(5), 466-477. 